\title{
THE DATING OF PEDRO DE VALENCIA'S SOBRE EL PERGAMINO Y LAMINAS DE GRANADA
}

Grace Magnier*

Pedro de Valencia's critique of the supposedly apocalyptic prophecy of St John the Baptist, el pergamino de la Torre Turpiana (1588), and the Lead Books (1595-1608) is entitled Parecer sobre el pergamino y láminas de Granada. It consists of two parts, in the first of which he reviews the critiques of the pergamino made by the biblical scholar Benito Arias Montano and by Juan Bautista Pérez, Bishop of Segorbe. In Part II the cronista del reino expounds his own arguments. There is a problem, however, with the dating of the document. Of the two MSS in the Biblioteca Nacional in Madrid one is dated "26 de nobiembre de 1607" and the other has the same date and month but the year is given as $1618^{1}$. A further copy in the Archivo Secreto de Cuatro Llaves of the Abadía del Sacromonte in Granada also gives the date as 1618. What is the explanation?

There would appear to be ample evidence to show that the Parecer was sent to Bernardo de Sandoval y Rojas, Archbishop of Toledo and Inquisitor General, in 1618. On the flyleaf of the copy which is lodged in the archive of the Sacromonte, the 1618 date is given. There is also a reference to the supposed retraction by Valencia and others of his group. An important fact, that undoubtedly explains why so many papers of Pedro de Valencia have disappeared, is also mentioned:

El Tribunal de la Suprema Ynquisision [sic] mando recoger este papel, y otros de los referidos Mendiola y Gurmendi",2.

* University College Dublin.

1. Pedro de VAlencia, Para el illustrisimo cardenal arçobispo de Toledo, Don Bernardo de Rojas y Sandouat, mi señor. Sobre el pergamino y laminas de Granada, MS 2316, ff. 1r-30r and MS 7187, ff. 116r-138r, BNM, and MS Flo. 138, vt. invent. 2, Leg. VI-VII, ff. 143r-163v Archivo Secreto de Cuatro Llaves de la Abadía del Sacromonte, Granada. The date on MS 2316 is 26 November 1607 and that on the other two is 26 November 1618. References to the text will be to my edition to be published by Exeter Hispanic Texts.

2. Archivo Secreto de Cuatro Llaves, Abadía del Sacromonte, leg. VI, fol. 1r. Francisco Gurmendi and Dr. Martín de Mendiola SJ both opposed the authenticity of the Lead Books. 
I shall return to discuss the historical circumstances surrounding this submission of the critique in 1618 but would first like to consider the earlier date. Miguel José Hagerty, in his edition of the translation of the plúmbeos by Adán Centurión, Marqués de Estepa ${ }^{3}$, states the following:

"Después de muchas consultas entre Roma y Madrid, Felipe III decide convocar una junta. El duque de Lerma, en carta fechada el 28 de octubre de 1607, encarga al arzobispo de Toledo la organización de aquella junta que se reúne en diciembre del mismo año"».

Could this committee have been the reason why Valencia wrote the Parecer in the first place? He states in the opening paragraph:

"Mándame Vuestra Señoría Illustrísima le diga por escrito mi parecer acerca de la verdad y autoridad del pergamino, y rreliquias, y láminas, y libros que se an hallado en Granada en la torre, y en el monte, el año de 1588 y el de 1595 [...] si aora me fuese lícito, bien quisiera diferir el cumplimiento de éste. Díceme Vuestra Señoría Illustrísima que antes requiere prisa $[\ldots]^{\prime \prime 5}$

It is apparent, thus, that the critique is being written at the request of Sandoval $\mathrm{y}$ Rojas and that it is needed in a hurry. In this year of 1607 a précis and an analysis of the first two of the Lead Books, Fundamentum ecclesiae and Essentia Dei, as well as the pergamino and other artefacts, had been sent to Pope Paul V (1605-1621) in Rome by the Morisco Jesuit, Ignacio de las Casas ${ }^{6}$. Both had been written at the request of the papal Nuncio Domenico Ginnasio (1600-1605) who by 1607 had been replaced first by Giovanni Garzia Millino (1605-1607) and then, on 22 May 1607, by Decio Caraffa (1607-1612) ${ }^{7}$. Paul V was known to be very sceptical about the Granada

3. A. CENTURIÓn y CóRDOBA, marqués de Estepa, Informacion para la historia del Sacro monte, llamado de Valparaiso y antiguamente Illipulitano junto a Granada. Donde parecieron las cenizas de S. Cecilio, S. Thesiphon, y S. Hiscio discipulos del apostol, unico Patron de las Españas, Santiago. Yotros santos discipulos dellos y sus libros escritos en laminas de plomo. Primera parte, Granada, Bartolomé de Lorenzana, 1632.

4. M.J. HagerTy, Los libros plúmbeos del Sacromente, Madrid, Nacional, 1980, p. 43. Hagerty, unfortunately, doce not give a source for this letter. Given that Hagerty is from Granada, I assume the source to be the Abadía del Sacromonte.

5. VAlEnCIA, Pergamino y láminas, p. 1.

6. P.I. de las CASAS, Informaçion de las laminas, libros y lo demas hallado en la çiudad de Granada, y cerca de ella el año de 1588 hasta el de 1598. Dada a nuestro Santissimo Padre Paulo V por Ignacio de las Casas de la Compañia de IHS este año de 1607, MS 7187, fol. 68r.

7.

Carlos Alonso states that las Casas had previously been asked to write a report on the Morisco by Clement VIII which he duly did and which was sent en 1 July 1600. Clement VIII on reading this report wrote on the back: "este negocio de los moriscos fue muy mal enfocado desde el principio y asi ha ido siempre de mal en peor": C. AlOnSO, Los apócrifos del Sacromonte, Valladolid, Estudio Agustiniano, 1978, p. 165. Boronat y Barrachina refers to a report called Informaçion acerca de los moriscos de España dada al Sanctissimo Padre Clemente VIII. He found it in Pascual Gavangos's Catalogue of Manuscripts in the Spanish Language in 
finds. Las Casas, in his Informaçion, had referred to the papal bull of Clement issued en 15 December $1603^{8}$. This had asked that the Lead Books be sent to Rome. Las Casas had again urged Clement to have the books taken to Rome in $1604^{9}$. Had pressure from the papacy increased in 1607, spurring the Council of Castile to contact Sandoval y Rojas who then requested Valencia to write his report? ${ }^{10}$ Perhaps this led to the letter from Lerma referred to by Hagerty? (see note 4).

Could the request by the Archbishop, to which Valencia refers in his opening paragraph and that I cite above, have been made in 1618? By then Valencia's hostility to the apócrifos de Granada was apparent to everybody; he had publicly supported Francisco Gurmendi's translations of the first two of the Lead Books and the critique or libelo that the latter had written in conjunction with the Jesuit theologian Dr. Martín de Mendiola. Sandoval y Rojas himself was, by this time, a supporter of the plumbeos. Although initially a patron of Valencia, would he have asked him for a critique under these circumstances? One must also take into consideration the health of the Archbishop; Sandoval y Rojas was very ill in 1618 and in fact died on 7 December $1618^{11}$.

I also believe that there is internal evidence in the critique itself to shown that the document could have been written in 1607. At the beginning of Part II, Valencia expreses his diffidence at putting his ideas on paper; public opinion in Granada has already decided, in anticipation of official Church recognition, in favour of the artefacts:

"Todas las prouanças y diligençias se an hecho después de declarados los poderosos, y el pueblo todo en fauor. Porque luego, como se allaron las reliquias, se reçiuieron con veneraçión, y deuoçión, y como se descubrió el monte, se cubrió de cruces y de concurso de gente" ${ }^{\prime 2}$.

The British Museum, I, sig., Add. 10. 238, p. 231: P. BORONAT y BARRACHINA, Los moriscos españoles y su expulsión, II, Valencia, Imprenta de Francisco Vives y Mora, 1901, p. 56.

8. LAS CASAS, Informaçion... fol. $68 \mathrm{r}$.

9. ALONSO, op. cit., p. 175.

10. ALONSO, op. cit., p. 182.

11. Professor Morocho Gayo considera that the Parecer was requested by Sandoval y Rojas in August at a committee set up at the request of the papacy: Humanistas españoles: Pedro de Valencia, V: Relaciones de Indias, I, Nueva Granada y Virreinato de Perú, ed. F. Javier \& J. Fuente Fernández, León, Universidad de León, 1993, p. 63. I hope to prove that, although the Parecer was certainly submitted in 1618 it was first written in 1607 .

12. VAlEnCIA, Pergamino y láminas, p. 8. The context for this quotation is the following: "Yo lo he reusado hasta aora por hauer hechado de ver luego, dende el prinçipio, que la piedad de la causa y la consideraçión que an hecho el Sr. Arçobispo y la Ciudad de Granada, como de propio onrra i interés grande, an lleuado tras sí el aplauso vnibersal de el vulgo, digo de muchos, y an antiçipado el juiçio. Esto es, han hecho praejudiçio sin esperar el conocimiento de causa y el egsamen que tan graue materia requería". 
This "concurso de gente" could at times take on the form of a jubilant carnival. In a large book, whose length belies its title, called Relacion breve de las reliquias que se hallaron en la ciudad de Granada en una torre antiquissima y en las cauernas del Monte Illipulitano de Valparayso cerca de la ciudad: sacado del proceso y averiguaciones q(ue] cerca dello se hizieron ${ }^{13}$, the miracles reputed to have taken place through the intercession of the "martyrs of the Sacromonte" are set down in great detail. On 15 May 1595, the feast of the followers of Santiago, the death of these "martyrs" was celebrated in spectacular fashion. At nightfall the guild of the cereros honoured St Cecilius; sumptuous arches were built out in the street:

"En el uno estaba la imagen de S. Cecilio, y en el otro una estatua de Neron hecha de cohetes, y invenciones de fuego, que con mucho regocijo vio el pueblo arder".

The dowager Duchess of Sessa, foundress of las Monjas de la Piedad, in this same year, organised a spectacular procession. In it walked over 1000 women carrying lighted candles and there were two dozen children dressed as angels. Accompanied by chirimias, the group processed up the Sacromonte where they set down a cross $^{14}$.

Such carnavalesque displays of mass piety were anathema to Valencia. He condemns them in the strongest of language believing them to be satanic in inspiration:

"Astuçia antigua a sido ésta del enemigo de la gloria de Dios acometer y procurar ganar primero a la $E^{15}{ }^{15}$, la parte más flaca y más blanda de la repú-

13. Relacion breve de las reliquias que se hallaron en la ciudad de Granada en una torre antiquissima y en las cauernas del monte Illipulitano de Valparayso cerca de la ciudad: sacado del proceso y averiguaciones q[ue] cerca dello se hizieron, II, Lyon, 1706. Con grabados de Francisco Heylan. Con privilegio del rey catholico y permiso de los superiores, sig 5/707, RAH. The absence of a publisher's name and the printing in Franco during the War of the Spanish Succession may have been due to fear of Inquisitorial opposition. The engravings of Francisco Heylán, whose years of activity were 1622-1631, were probably sent to Franco from Granada. (The copper platos are to-day stored in the Abadía del Sacromonte.) The libros plúmbeos had been rejected as falsifications by a papal bull promulgated on 26 March 1682. I am indebted to professors D. W. Cruickshank and L.P. Harvey for making me aware of these publication incongruities.

14. Relacion breve..., pp. 46-47.

15.

Elsewhere in Valencia's writings this rather obscuro phrase is elucidated: «Hizo Dios, pues, a los hombres varon y hembra: no solamente en lo exterior y visible fueron dos, Adan varon y Eua mujer, sino que en lo interior cado uno de ellos de por si tenia dos partes, una el hombre interior, que es varonil, y le pertenece el Dominio y govierno y se llama espiritu y porcion superior, y otra la parte inferior y femenina en que estan los sentidos y apetitos corporales qve deve ser obediente y conformarse con la parte superior y se llama en escritura anima. Acordó y compuso Dios estas dos partes en tan concentrada armonia y concerto, unio y junto en tan conforme matrimonio los dos en una carne mediante la comunicacion de su luz, favor y graçia que no solamente no se contradecian ni estorvavan el uno al otro, 
blica, y persuadir al bulgo ignorante de vn culto como que sea religioso. Porque persuadido éste, llena tras sí (o los sigue cuando preceden), a los poderosos cuyo consejo de estado es, agradar a los más, a la turba bulgar cuya condiçión y de todos los descuydados de la virtud, y verdadero culto de Dios, suele ser lisongearle, y quererle satisfacer con exterioridades y culto de los labios" ${ }^{\prime 16}$.

The above "festivities" took place in 1595, the year in which the first of the Lead Books was found. Benito Arias Montano had sent his critique of the pergamino to Archbishop Castro en 4 May $1593 .{ }^{17}$ The editors of volume V of Valencia's Obras completas feel that Valencia's participation in the composition of this is probable. ${ }^{18}$ In any case Arias Montano visited Valencia at Zafra towards the end of August in that year. ${ }^{19}$ News of the excitement in Granada as the first of the Lead Books was found in 1595, and the spectacular manner in which [he finds were celebrated by the people, would surely have reached Valencia, who still lived in Zafra at that time. Such memories would be more vivid for a report written in 1607 than for one written in 1618 , a full twentythree years later.

\section{THE CRITIQUES OF VALENCIA AND GURMENDI}

Should the critique of Valencia have been submitted for the first time in 1618 it is possible, and perhaps likely, given their Glose association, that his work would reflect some of the ideas of Francisco Gurmendi. As I have poin ted out on page 1, the Parecer reviews, in Part I, the critiques of Arias Montano and Segorbe. Gurmendi's libelo is not referred to. Conversely, should Valencia's work have been written first, some of his ideas might possibly be found in the libelo of Gurmendi.

Francisco Gurmendi (d. 31 March 1621) is described in a letter of Philip III as a "criado de su magestad"20. He came from Guipúzcoa and as a child

sino antes se ayudavan y juntavan para engendrar y producir pensamientos y obras virtuosas en obediencia, y para loor y gloria de su creador»: Discurso sobre materias del Consejo al Estado dirigido a una persona que le pidio dictamen, MS 11160, BNM, ff. 32v-33r. Thus "Eua" stands for the senses and appetites unguided by the spiritual and non-material anima.

16. VAlEnCIA, Pergamino y láminas, pp. 8-9.

17. D. Cabanelas RodrígueZ, Aries Montano y los libros plúmbeos de Granada, MEAH, XVIII-XIX, 1969-1970, p. 21.

18. Whether or not Valencia was involved in the composition of the critique he certainly had it to hand when writing his own report, as I document in my edition of the text.

19. VALENCIA, Relaciones de Indias, I, p. 28.

20. "Orden para que el Padre Prior de S. Lorenzo el Real haga recibir en aquella casa en déposito de librería del Rey Cidan que se ha mandado á Francisco de Gurmendi, que haga llegar allí y se halle presente á la entrega della", C. PÉREZ PASTOR, Bibliografía madrileña, II, Madrid, RBAM, 1906, p. 333. 
came to Madrid where he lived in the household of Juan de Idiáquez (1540-1614), also from Guipúzcoa, former secretary of Philip II and President of the Council of the Military Orders under Philip III.

In 1612 Gurmendi was entrusted with the cataloguing of the library of Muley Cidan, which had been requisitioned in the port of Mamora in that year by part of Philip III's navy. In a letter from the king to the Prior of El Escorial, dated 7 May 1614, he is described as "Francisco de Gurmendi, mi criado, que me sirve en la traduccion é interpretacion de las lenguas Arabiga, Turquesca y Persiana". In this letter the king appoints Gurmendi as supervisor of the books now to be transported to the Escorial. He is further entrusted with the separation of those books which are prohibited from the others (there were, apparently, more than two thousand commentaries on the Qur'an, two of which are referred to in the libelo).

This library may have been used as a source for the book on kingship written by Gurmendi. Called Doctrina phisica y moral de principes, it was published in 1615 and purports to be based on the writings of many Arab philosophers ${ }^{21}$. Initially I would have agreed with José Antonio Maravall ${ }^{22}$ that its claim of being a translation from Arabic may have been a fiction such as that used by Miguel de Luna in his Historia verdadera del rey don Rodrigo and parodied by Cervantes in the Quijote ${ }^{23}$. However two things have made me reconsider my view. Gurmendi's appointment as interpretar of Oriental languages to the king, following the death of Miguel de Luna in 1615, and his cataloguing of Muley Cidan's library, presuppose some familiarity with Arabic. Gurmendi's skills as a linguist are extolled by Juan Bautista de Pastrana in a prefatory poem printed in the Doctrina phisica:

\footnotetext{
"Criandose en Madrid desde pequeño con el dueño el Idiaquez peregrino, sea en la lengua arabiga ladino y entienda al Afro, Assio y al Isleño. Raro aprender de lenguas, pues en suma las traduze y entiende, y aun comenta, y aquel estilo infiel buelue Christiano"24.
}

Secondly, Gurmendi's libelo, or defence of the accuracy of his translations of the first two of the Lead Books, shows quite an awareness of Arabic

21. F. de GURMENDI, Doctrina phisica y moral de príncipes, Madrid, Andrés de Parra y Gaspar García, 1615.

22. J.A. MaraVAll, Teoría española del estado en el siglo XVII, Madrid, Instituto de Estudios Políticos, 1944.

23. P.L. HARVEY, The Moriscos and Don Quixote. Inaugural Lectura in the Cervantes' Chair of Spanish Delivered at University of London, King's College on 11 November 1974, London, King's College London, 1975.

24. This is citad in the entry under Gurmendi in PÉREZ PASTOR, Bibliografía, II, p. 333. 
style and grammar (there were many dictionaries in the library of Muley Cidan). He also refers to some commentators of the Qur'an, many volumes of which were to be found in Muley Cidan's library, as I have mentioned above. Possibly, then, the claim by the author is to be taken at face value. The negative views of Gurmendi's skills as a translator all seem to stem from supporters of the Lead Books ${ }^{25}$. Gurmendi himself was aware that there were lacunae in his knowledge and so recommends in the libelo that more expert translators be consulted ${ }^{26}$.

The privilegio for the Doctrina phisica y moral de principes was granted in 1614 and the book was published in 1615. Although it does recommend that the Prince should always appear to be virtuous it would not appear to be Machiavellian in its substance. What is more interesting, however, are the enjoinders to the advisers of the king. Gurmendi in fact uses the term privado and has many overt warnings against unsuitable ministers ${ }^{27}$. The king must exercise great vigilance and carefully supervise those who govern in his name:

"Por eso el rey ha de mirar cõ muy claros ojos y velar sobre los que gouiernan y aconsejan para deshazer toda tirania, castigar toda culpa y premiar todo buen seruicio" ${ }^{28}$.

Given the period in which it was published the associations with Lerma are inevitable. However, the fact that it has been dedicated to the Duke himself does seem rather strange in this context. Is this dedication merely a nod to convention? Or is the dedication to Lerma, which implicitely accepts him

25. "Y diziendo el [Gurmendi] que es interprete no haze esse officio sino de calumniador im prudentissimo [...] Fran Gurmendi es incapaz y no idoneo para interpretar ni entender estos libros": Memorial contra Gurmendi en el Consejo, 20 de febrero de 1618, AS, leg. VII, I, fol. 940r.

26. Gurmendi recommends the Archbishop of Montelíbano, and the Turk Marco Dobelio, both of whom had acted as translators from Arabic to Pope Paul V: GuRMENDI, Libelo, leg. VI, AS, fol. 853r.

27. " [...] a este tal rey, con los muchos y malos ministros, le podemos comparar a vil hombre que lleua vna piedra pesada al hombro, que solo le sirue de cansancio y pesadumbre, no hallando por ella ningun valor ni precio, pero el rey que se sirue de ministros buenos (aunque sean pocos) es como el que llena una piedra diamante, o rubi que no le haze peso y le haze rico en la ocasion que ha menester aprovechar de su valor": GURMENDI, Doctrina phisica, fol. 100r.

28. GuRMENDI, Doctrina phisica, fol. 101v. Professor D.W. Cruickshank has pointed out that, since the re-introduction of the post of privado in 1598 political theorists had tried to advance their careers by justifying this position. Two examples are Miguel Yelgo de VÁzQuEZ, Estilo de servir a príncipes, Madrid, Cosme Delgado, 1614, dedicated to the Duke of Uceda, son of Lerma and Lorenzo RAMíREZ de PRADO, Consejo y consejero de príncipes, Madrid, Luis Sánchez, 1617, dedicated to the Duke of Lerma. The dedication of the Doctrina phisica is in fact to the Marqués of Denia, a title cited as one of Lerma's as late as 1618 in Jaime Bleda's Coronica de los moros de España. 
as a "suitable" minister, a stratagem for getting the book past the Council of Castile, then controlled by Lerma. It should also be pointed out that 1618, the year when the controversy about the authenticity of the Granada finds was at its height, is also the year in which Lerma was "invited to retire" (4 October).

\section{GURMENDI'S TRANSLATIONS OF AND COMMENTARY ON TWO OF THE LEAD BOOKS}

Among the papers Gurmendi found after Idiáquez's death in 1614 were copies of the characters of the first two of the Lead Books, Fundamentum ecclesiae and Essentia Dei. These he duly translated and sent copies to Philip III in March of 1616. Copies were also sent to Rome on 6 May $1617^{29}$. These, I believe, were the first actual translations to be sent there. Pedro de Castro, by then Archbishop of Seville, had a memorial printed criticising Gurmendi's translations. Aided by the former Jesuit Dr. Martín de Mendiola (he had been expelled from the Jesuits for opposing belief in the Immaculate Conception), Gurmendi then wrote a libelo in May of 1617 to put forward their objections to the authenticity of the artefacts and to refute the arguments of Castro's memorial. This libelo was presented to Philip III in October of 1617. According to the relics forger Cristóbal de Medina Conde, Gurmendi's libelo was also sent to the Royal Council and to that of the Inquisition ${ }^{30}$. Gurmendi's translations and this libelo of 1617 were a source of great controversy and were much criticised at court. As a supporter of Gurmendi Valencia was deeply implicated in these events.

\section{GURMENDI'S LIBELO}

Gurmendi's libelo was written at the request of Philip III. The kin's desire was relayed by Fray Luis de Aliaga, the king's confessor, who did not believe in the authenticity of the plumbeos $^{31}$. At the beginning of the libelo Gurmendi states that his motives in writing it are "la honrra y gloria de Dios". It is divided into two parta, the first of which concentrates on the language used and the second on doctrinal errors. The tone is most forthright and his condemnation is couched in strong language: "los libros hallados en

29. Alonso, Apócrifos, p. 212.

30. C. de MEDINA CONDE, Informe a los eruditos sobre la oposicion que hicieron a los descubrimientos antiguos de Granada el famoso antiq ${ }^{\text {ro }}$ Pedro de Valencia y otros literatos, MS 1271, BNM, fol. 34v.

31. Alonso, Apócrifos, p. 212. 
el monte de Valparayso de Gra ${ }^{\text {da }}$ son patraña y imbencion morisca". He criticises the competence and objectivity of previous interpreters used by Archbishop Castro:

"el Arzobispo de $\left.\mathrm{Seu}^{\mathrm{a}}{ }^{\circ}\right]$ auia hecho las diligencias posibles $\mathrm{p}^{\mathrm{a}}$ calificar lo q[ue] toca al dho monte de valparayso, que es lo que el comun llama laminas, libros y otras cosas $\mathrm{s}^{\text {as }}$, y como sea anssi, que para este fin se valiese de interpretes no tan sabios como era menester y quiza apasionados y sospechosos ${ }^{32}$.

At times he uses ridicule against Castro s memorial. He suggests that the authors of this should consult Arabic dictionaries or at least experts in the language:

"A lo qual puede responder el author del dho papel dado por el Arzobispo de Seua, lo que respondiera un ciego si la mandaran que juzgara de colores" ${ }^{\prime 33}$.

He points out that two styles of Arabic are used; one is that of the Moriscos of sixty or seventy years previously and the other is classical Arabic. The latter tends to take the form of quotations from the Qur'an which is disguised, however, by being written out in prole. The transition is often so abrupt that it is very obvious:

"[...] sale el lenguaje del Alcoran como lo blanco sobre lo negro" ${ }^{34}$.

He states that the Arabic is African rather than Oriental and that many Castilian and Latin words are used because of ignorance of the Arabic ones ${ }^{35}$. The absence of vowels does not of necessity imply that the work is old, as alleged in Castro's memorial; rather it implies the contrary:

"[...] en el qual se dice [...] que en estos libros del Monte de Valparayso no ay vocablos ni puntos sustanciales con q[ue] prueua ser antiguos los dhos libros: en lo qual enormemente se engañaron por q[ue] el usar de vocales en la lengua arauiga es ad liuitum de tal manera que el no auer uocales antes es argumento de que son modernos, porque antiguamente se usaban casi tantas, como las que vsan los poetas, $\mathrm{y}$ libros profundos de la lengua arauiga ${ }^{36}$.

32. GURMENDI, Libelo, leg. VI, AS, fol. 85or.

33. Ibidem, fol. 856v.

34. Ibídem, fol. 851r.

35. Ibídem, fol. 852r.

36.

Ibidem, fol. $852 \mathrm{v}$. This assertion by the authors of the libelo is only partially true. It is true that vowels have always been used in poetry. The term "libros profundos" is rather vague. If it is being applied to the Qur' $\bar{a} n$ then it is true that vowels were used there (in the later writings) to ensure that the meaning was not opera to misinterpretation. However, in the case of Qur'anic commentary this was not always so. Pre-Islamic works would not have used vowels and as the Lead Books purport to be from the first century of the Christian era 
As there are many quotations from the Qur'an in the Lead Books the authors rather logically points out that they could not have been written in apostolic times ${ }^{37}$. He traces direct quotation from two Qur' anic commentators: Ebu el Leit el Samarcandi ${ }^{38}$ and Mahamed [sic] bin Abdala bin Latib ${ }^{39}$.

\section{THE LEAD BOOKS'ATTACK ON THE TRINITY}

The libelo points out that in the Arabic translation of some verses of Chapter I of the Gospel of John, which is contained in the pergamino, some words are omitted. This is done in such a way that attributes of "the Word of God", as represented by Jesus, second Person of the Trinity, are applied instead to St. John ${ }^{40}$ :

"Todo esto pues dize el autor destos libros era: 'aquesto fue vn hombre
llamado Juan', ya se entendera quan lejos estaba este Autor de confessar que

then the absence of the vowels could be held to prove their antiquity. This dating, of course, is refuted by the presence of Qur'anic texts in the plúmbeos. It is obvious that neither the authors of the plumbeos nor the writers of the libelo were fully au fait with the linguistic patterns of Classical Arabic. I am grateful to Professor K. Cartwright and to Dr. D. Morray, Department of Middle Eastern Studies, National University of Ireland, Dublin, for the above information.

37. GURMENDI, Libelo, leg. VI, AS, fol. 853v.

38. This is possibly Abu 'l-Layth al-Samarkandi, Nasr B. Muh. B. Ahmad B. Ibrahīm, called the Imam al-Hudā, a Hanafi, theologian and jurisconsult. He died in either 373/983-984 or 393/1002-1003. He wrote a Tafsīir, or Qur' annic commentary, which was published in Cairo in the last century (1310/1892-1893): Encyclopaedia of Islam, I, Leyden, Brill, 1960, p. 137.

39. GuRMENDI, Libelo, leg. VI, AS, fol. 854r. Could this be Muhammad 'Abd Allah B. Tahir Dhi 'l-Yamīna Abu '-'Abbas? He was born in 209/824-825. He was both the military governor of Baghdad and a scholar. He was a relator of Hadiths or Islamic traditional beliefs: Encyclopaedia of Islam... VII, P. 390.

40. This is the context for the following judgement: "Iten dize en el mismo evangelio traducido en arauigo, que todo quanto auia acabado de dezir el Euangelista es a saber: omnia per ipsum Pacta sunt, et sine ipso facttum est nihil, quod factum est in ipso vita erat lux hominum, et lux in tenebris lucet. Lo qual se lo atribuyen al Verbo Divino los sagrados concilios y padres, como doctissimam ${ }^{\text {te }}$ lo demuestra atribuyen padre Juan de Maldonado, sobre dicho lugar": GURMENDI, Libelo, AS, leg. VI, fol. 862v. I have checked this in the versions of del Castillo and de Luna. The translation is different but the substance is the same: “[...] y la luz resplandeçe en las Tinieblas y las Tinieblas no le comprehendieron. Fue vn hombre enbiado de Dios llamado Joan y vino para testimonio a enseñar de parte de Dios para que todos en el creyesen y era luz verdadera que con ella alumbra toda criatura en el mundo [...]": M. de LuNA, Tratado i traduction de todo lo contenido en el pergamino dentro de la caxa de Plomo que se hallo con otras Reliquias en la torre vieja desta sancta yglesia de Granada el sabado Pasado dia de sant Joseph diez y nueve de março deste año de mill y quientos ochenta y ocho [ $\left.{ }^{\circ}\right], 31$ de março de 1588, AS leg. VI, fol 407r. A comparison with the Castilian version in a modera Bible shows that a crucial sentence has been omitted. Verse 8 , which refers back to the coming of John reads "No era la luz sino que vino a dar testimonio a la luz": Sagrada biblia, trans. E. Nácar Fuster \& A. S. Colunga, Madrid, BAC, 1958, p. 1152. 
auia Verbo Diuino, pues lo que era propia suyo se lo atribuye a S. Juan, heregia desbaratada, nacida mas de sobra de malicia, que de delgadeza de entendimiento" $"$.

The divinity of Christ is also omitted in another adulterated passage. This is done by changing this same opening passage of the Gospel of John. For "In principio erat verbum" there is substituted for "verbum" the noun "locutia". The author claims that this terminology was also used by some early Fathers of the Church like Tertullian in Adversus Praxeam:

"Praeterea, al principio del dho Euangelio en lugar de dezir 'In principio erat verbum' dixo 'in principio erat locutia el locutia erat apud Deum, el Deus erat locutia'. De todo lo qual euidentem ${ }^{\text {te }}$ se infiere que el dho autor sentía no auer Verbo Diuino; pues en todos los lugares, en que se le ofrecía ocasion de hablar desta Persona lo dexa y pone en lugar della cosas bien agenas de catolicos [sic]; lo qual dize el teologo, porq[ue] la version referida aunq[ue] fue de algunos padres antiguos, como son Tertuliano lib. de Trinit et in lib. Adversus Praxeam"42.

Pedro de Valencia also takes up this point but argues it in a much more lucid way.

The libelo also refers to the adulterated form of the Shaháda, the Islamic profession of faith, which is found in the plumbeos. The Islamic version is as follows: "No hay Dios sino Dios y Mahoma, embajador de Dios." This comes at the end of the Lead Book De essentia Dei. Gurmendi compares it with the thirty-odd references to the Šhahäda in the Qur'ān which the writer has seen in the Qur'anic commentaries from Muley Cidan's library. The version of the Šhahäda found in De essentia Dei is a direct copy from the Qur'ān ccording to Gurmendi. Other translators do not agree. Adán Centurión, Marqués de Estepa, translated the phrase as "No hay Dios sino Dios y Jesús, Espíritu de Dios"43. The spurious version is used, of course, to negate the divinity of

41. GURMENDI, Libelo, AS, leg. VI, fol. 862v.

42. Ibidem, ff. 862v-8630. This assertion is not corroborated by the version of either del Castillo or de Luna. Both Moriscos translated it as «En el prinçipio era la palabra»: A. del CASTILlo, Traducçion de lo que esta escripto en Arabigo en el pergamino que estaua junto con las reliquias en la caja de plomo que se hallo entre las piedras con otras reliquias en la torre vieja desta san ${ }^{\text {ta }}$ yglesia de granada, 5 de abril de 1588, AS, leg. VI, II, fol. 2r; LUNA, Tratado y traduction, fol 3v. The role of John the Baptist, precursor of the Messiah, is attributed to Jesus who, it was claimed, had gone before Muhammad as the Baptist has preceded Jesus. Jesus was given the title of Messiah in the apocryphal Morisco gospel El evangelio de San Bernabé: L.F. BERNABÉ PONS, El evangelio de San Bernabé: un evangelio islámico español, Alicante, Universidad de Alicante, 1995, pp. 109-110.

43.

Estepa's translation has been edited by Miguel José Hagerty (see footnote 4). The editor includes the following footnote: En vez de "Espíritu de Dios" Estepa tradujo ruh Allah "Hijo Encarnado de Dios", o "Verbo Encarnado" a lo largo de su versión de los plomos. En una nota explica así su razonamiento: "Donde aquí y en otras partes traducimos Verbo Encarnado de Dios, en árabe ruh Allah, que a la letra dice Espíritu de Dios. Mas en 
Christ. It would appear that Castro's memorial translates the phrase as "No hay Dios sino Dios y Mesías, enviado de Dios". The libelo refutes this by pointing out that the Arabic version lacks the definite article which is necessary for this meaning. Without the article the word is translated as "Mahoma":

“[...] las dichas palabras son trasladadas verbum ad verbum del Alcoran de Mahoma [...] en donde no dize Mesias sino Mahoma [...] era menester que huuiese este articulo. el. al principio segun el idioma Arauiga, lo qual falta en el dho lugar" ${ }^{\prime 4}$.

In Part III of the libelo there is a further elaboration:

"Dize pues en el fin del $2^{\circ}$ libro "No ay otro Dios que Dios, Mesias" o, como otros trasladan, "Mahoma embaxador de Dios". [ ["] "No hay otro Dios q[ue] Dios palabras al parezer catolicas pero a los versados en el Alcoran de Mahoma mas les escandaliza q[ue] todo quanto sea tocado, porq[ue] en todo el dho Alcoran no se topara que diga Mahoma estas formales palabras 'En Dios ay Trinidad de Personas' sino solo dize "No ay otro Dios que Dios Mesias, espiritu de Dios"45.

The arguments concerning the Trinity continue in the extensive elaboration of the Nestorian image of Mary as the mirror through which Jesus was associated with God the Father:

"[...] dize assi, en el primero libro al medio del: 'Pues yo te explicare la Vnidad o vnion Triplicada con este exemplo. El Padre miro en el espejo y con la luz $\mathrm{s}^{\text {to }}$ spiritual aparezio el hijo en el espejo; fue pues Maria el espejo".

esto traducimos el sentido que se colige de antiguos padres que expresan este término y en estos mismos libros se declara en la sentencia en el Libro de las Sentencias letra Ba' $\left.{ }^{\circ}\right]$ Ver infra p. 186. Precisamente en este libro los falsificadores ni siquiera ponían ruh Allah, sino la abreviatura en árabe mim ra' Allah, que bien podía leerse Mesih, ruh Allah, 'Mesías, Espíritu de Dios', o Muhammad, rasul Allah, 'Mahoma, enviado de Dios'. Por otra parte en el Corán, Jesús es llamado Mesías, Espíritu de Dios e incluso Verbo": HAGERTY, op. cit., pp. 70-71.

44. GURMENDI, Libelo, AS, leg. VI, fol. 856 ${ }^{\mathrm{v}}$. Dr. David Morray has pointed that the word for Messiah or Christ (the anointed) for followers of Islam is $\mathrm{Al}$-Masih which, as can be seen, has an article. He concurs that an article is never used before the narre of Muhammad. He also indicated that the Šahäda is not to be found in the two Surahs mentioned in the text, Surah Fataha and Surah Muhamedin. As can be seen from the previeus note, confusion about the translation may have arisen both because of the abbreviation used in El Libro de las Sentencias and the titles given to Jesús in the Qu'rān. One must also not forget, of course, that the plúmbeos are written in an adulterated form of Arabic.

45. GURMENDI, Libelo, AS, leg. VI, fol. 8671. Gurmendi goes on to state that he has seen this in many copies of the Qur'ān in both the library of El Escorial and in his own private library. The discussion on the various meanings of the $\check{S} a h \bar{a} d a$ is rather confusing in the libelo. In the above extract, for example, the translation "espíritu de Dios" is introduced without any explanation. 
The author of Castro's memorial claims that the mirror image is used as a metaphor for the Trinity. This is rejected by the authors of the libelo who point out that this idea is only accepted by the Nestorians arad the followers of Islam ${ }^{46}$. The mirror image implies one of other of the following heresies: Mary is co-eternal with the Trinity or the second Person is not co-eternal with God the Father ${ }^{47}$. Although Pedro de Valencia writes at length about Trinitarian doctrine he makes no reference to the mirror image.

\title{
VALENCIA'S PARECER
}

Valencia's criteria for judging the pergamino and what he believes to be the contents of the Lead Books are those of a biblical scholar. For example he refutes one interpretation of a possibly ambiguous passage in the Gospel of St. John by direct reference to the original Greek. In the pergamino, mistranslation was used to edit out a reference to the divinity of the Second Person of the Trinity:

\begin{abstract}
"Demás de esto, y en la misma razón, noto yo una no omisión sino comisión muy culpable, que demás de la infidelidad de la versión, descubre manifiestamente que se tradujo de la versión latina esta parte del evangelio de San Juan, que se lee en arábigo en el pergamino diçe: 'I vimos su gloria, así como somos criados del padre. Y la palabra fue llena de misericordia y verdad'. Esto se pudo traduçir de aquello latino: Et vidimus gloriara eius, gloriara quasi unigeniti a Patre, plenus gratiae \& veritatis [Io. I, 14]. Tomando la palabra unigeniti por nominatiuo plural, interpretando engendrados, o criados, o por maliçia or por grande ignorancia, la qual perversión no permite el griego $\mu$ ovo $\delta \rho \sigma^{״ 48}$.
\end{abstract}

46. Ibidem, fol. 860r. Las Casas also refers to Nestorianism in his Informaçion. However, Gurmendi, in a letter stored in the archive of the Sacromonte and written shortly before he died, denies having had any contact with las Casas: AS, leg. VII, I, fol. 768r.

47. “[...] el author del dho libro [...] declaro [...] o que la Reyna de los Angeles era quo eterna con el Padre eterno en su ser actual o que la segunda persona de la ss ${ }^{\mathrm{ma}}$ Trinidad no tiene ser coeterno al Padre, sino solo temporal, rezebido en las entrañas de la Reyna de los Angeles. A la qual llamo el espejo donde reziuio el ser que tiene la segunda persona de la ss ${ }^{\mathrm{ma}}$ Trinidad, con lo qual no solo sembraba la doctrina Nestoriana sino tambien la de Arrio": GURMENDI, Libelo, AS, leg. VI, fol 860v. Nestorianism claimed that Christ was made up of two distinct persons, one human and one divine. It refused to accept Mary as the Theotokos (God bearer) as this implied that the divine nature was born of a woman. It was accepted, however, if used in conjunction with the title Anthropotokos (man bearer). The preferred title was that of Christotokos. Nestorianism was condemned at the Council of Ephesus in 431. When Persia was conquered by the Arabs in 637 and during the 640's the Nestorian church was tolerated and thus became associated with Islam: New Catholic Encyclopedia, New York, London, MGraw-Hill, 1967, pp. 345, 347.

48. VALENCIA, Pergamino y láminas, p. 29. 
The Arabic passage from the pergamino, to which I referred in the last section, was obviously a translation from Chapter I, 14 of the Gospel of John in the Vulgate ${ }^{49}$. The libelo refers to this Chapter also but points to some earlier verses, 3-4. The intention is again to edit a referente to the divinity of Christ by ascribing the attributes of Christ to St. John as I explain in footnote 42 .

Valencia also refers to the Christianised version of the $\breve{S} a$ had $a$, found in the Lead Books: "no hay Dios sino Dios y Jesús espíritu de Dios". Referring to the phrase "Jesús, espíritu de Dios" he acknowledges that some of the Fathers of the Church, such as Tertullian and Lactantius, used the terco "espíritu santo" when referring to the "verbo divino" because he was a spirit and was holy. Christ, however, has never been so named:

“[...] aunque hubo autores christianos, en particular Tertuliano y Lactançio, que llamaron al Verbo Diuino "espíritu santo" porque es espíritu y es santo, pero a Christo, que es el verbo Encarnado, no sé que aya hauido escritor cathólico que se lo llame. Y aun los que lo llamaron [a él] Verbo Diuino, diçe san Gerónimo que lo hiçieron por ignorançia de las escrituras"

Valencia's criticism of the Christianised version of the $\check{S}$ ahăda, based on his expertise as a biblical exegete, is succinct and conclusive. This passage was also referred to by Gurmendi but his criticism was based en textual criticism of the Arabic.

Valencia also uses his knowledge of biblical texts to criticise the style of the language used in the pergamino:

“El charácter del stilo de Dios y de sus santos no son obscuridades afectadas con algarauías y gerigonças sino vehemeçia y manifestaçión de spíritu a que no pueden resistir los aduersarios todos juntos, y que causan admiraçión y confunden a los sabios y letrados del mundo. Esto es lo que en la escritura se llama magnalia Dei, aquella sabiduría y eloquencia inimitable, con que los apóstoles y santos hablan del misterio de la redempçión ${ }^{51}$.

Gurmendi and Mendiola do not use the criteria of biblical exegesis; rather their criticisms derive from Arabic style and grammar. Both libelo and parecer highlight the undermining of Trinitarian theology which is undertaken

49. The Castilian version of the Arabic commentary on the prophecy of st. John and the prophecy itself, both of which are contained in the pergamino, made by the Morisco translators Alonso del Castillo and Miguel de Luna, do translate "unigeniti" as "criados" in a mistranslation of John 1, 14: "[...] y la palabra se hizo carne y moro entre nosotros y vimos su gloria asi como somos criados del padre" ["Y el verbo se hizo carne y habitó entre nosotros, y hemos visto su gloria, gloria como de Unigénito del Padre": Sagrada biblia, p. 153]. LuNA, Tratado y traduction, AS, leg. II, fol. 3v. Del CASTILLO, Traducçion, AS, leg. II, fol. $2 \mathrm{v}$.

50. VAlEnCIA, Pergamino y láminas, p. 28.

51. Ibidem, p. 21. 
in the pergamino and Lead Books. Valencia very lucidly refutes the idea that the title "Jesús, espíritu de Dios" was ever part of the orthodox canon of the Church. The libelo explores the supposedly Nestorian image of the Trinity in which Mary serves as the mirror in which the Father looks and sees the Son. It would seem likely that Valencia did not have to hand the libelo of Gurmendi when drafting his Parecer; he carefully reconstructs the arguments of the critiques he did have, which were those of Benito Arias Montano and of Juan Pérez, Bishop of Segorbe. Gurmendi would also appear not to have made use of Valencia's Parecer.

\section{POLITICAL BACKGROUND TO THE PARECER OF 1618}

My attempt to establish which of the two dates on the MSS was the true one involved a study of the political background in 1607 and in 1618. Pressure from Rome between 1603 and 1607 finally forced Philip III to set up a committee to study the plúmbeos. He delegated this task to the Archbishop, Bernardo de Sandoval y Rojas, who requested that the recently appointed cronista del reino, Pedro de Valencia, should brief him en the matter. In spite of the brevity of time at his disposal (the request must have been made on or after 28 October) Valencia complied and the Parecer was finished by 26 November of that year.

By 1618 , the political climate had greatly changed. Influential factions at court supported the authenticity of the plúmbeos. Gurmendi, who had been greatly suppported by Pedro de Valencia, had by then circulated his translation of the first two of the Lead Books and his critique or libelo had given rise to great controversy. This had been sent to the King, the Royal Council, that of the Inquisition and to the Suprema itself in Rome in 1617. This action caused an enormous stir at court in the following years.

Two canons from the Abadía del Sacromonte were in Madrid to represent the interests of Archbishop Pedro de Castro, by then Archbishop of Seville. They were Don Francisco de Barahona and Don Antonio Tavares. Barahona acted as Castro's envoy at court. The correspondence between Barahona and Archbishop Castro gives some idea of the turmoil being created there by the plumbeos:

16 de enero de 1618 (Barahona to Castro)

"Bueluo a decir a VSS que se trata de los libros en el Consejo de Estado ${ }^{52}$. [...] En casa de $\mathrm{P}^{\mathrm{o}}$ de Valencia se juntan los emulos (de las Láminas): Gurmendi y Mendiola un clerigo theologo, que echaron de la compañia hara dos años, y

52. AS, leg. VII, I, fol. 920r. 
otros amigos a hacer sus consultas contra el Monte Santo, que esta tan empeñado en defender lo que ha dicho Gurmendi, que [este] para poder hacerlo mejor estudia la Philosophia y theologia. Muy persuadidos todos a salir con su intento de deshacer el Monte Santo $^{53}$.

Barahona was becoming seriously worried about the opposition of Pedro de Valencia's circle:

30 de enero de 1618 (Barahona to Castro)

"Los bien afectos y prudentes an reparado en la mansedumbre con que V. S. I. lleva este negocio, en el recato que tiene en manifestar lo que es [...] entra luego la ocasion para los mal intencionados y diran porque no decia lo que el $\operatorname{arçob}^{\circ}$ de Seuilla queria, y este dicho tiene la cama tan hecha con lo que a dicho Marcos [Dobelio] y Gurmendi, y con lo que los an creydo el $\mathrm{p}^{\mathrm{e}}$ Confessor y el Nuncio con lo que los an ayudado $\mathrm{P}^{\mathrm{o}}$ de Valencia y D. J ${ }^{\mathrm{n}}$ Fonseca que aunque sea dicho sin fundamento es mucho de temer" ${ }^{\mathrm{5} 4}$.

In another letter to the Archbishop he reassures the letter of the lack of substance of the arguments of the opponents. However, he is still very concerned at their influence on others: 6 de febrero de 1618 (Barahona to Castro)

"Bien veo quan poco fundamento tienen lo [sic] que oponen; mas mi cuy dado mayor es del efecto que esto que dicen tal y cual hacen en los pechos de los que lo oyen y no cuydara de otra satisfaccion ni examen. Muy grande es el alboroto que ay sobre el caso" ${ }^{\text {"55. }}$.

Barahona feared that should Valencia write to Rome this would damage the case for the recognition of the plúmbeos. On 15 and 16 February and on 2 March letters were sent to Pedro de Valencia to impose the papal brief that forbade any discussion of the issue.

28 de febrero de 1618 (Barahona to Castro)

"A don $\mathrm{Ju}^{\mathrm{n}}$ de Fonseca no se a notificado ni notificaran los breves a $\mathrm{P}^{\mathrm{o}}$ de Valencia. Si mandolo V. S. I. en la carta que tengo aqui y a convenido. No sabe Arabe pero ayudase del que lo sabe para justificar su sentimiento; que basta que ponga en duda lo del Monte sea por saber Arabe o saber latin. $\mathrm{P}^{\mathrm{o}}$ de Valencia respondio a la notificacion que el daria cuenta a su $\mathrm{S}^{\mathrm{d}}$ de lo que le parecia. Esto pienso que hara daño en Roma"56.

53. VALENCIA, Relaciones de Indias, I, p. 58.

54. AS, leg. VII, I, fol. 920r.

55. AS, leg. VII, I, fol. 920r. The italics are mine.

56. AS, leg. VII, I, fol. 959v. 
Barahona recognised that Valencia's opposition did not arise out of malice. He was also aware of Valencia's courageous insistence on speaking his mind:

30 de febrero de 1618 (Barahona to Castro)

"No deue de mouer a $\mathrm{P}^{o}$ de Valencia mala intencion sino hallar dificultad en el hecho y antiguedad de lo del Sacromon ${ }^{\text {te }}$ como se precia de tan versado en letras y lenguas y debe de estar asido tanto a sus dificultades que respondio a la notificacion de los breues, que aunque obedecía, y no auia jamas ydo contra lo que en ellos se contenía pero que no dexaria de dar cuenta de lo que sentia acerca del $M^{\text {te }} S^{\text {to }}$ a su $S^{d}$ de Paulo Vy a los ministros que esto tuuiese ordenado. Por esto entiendo yo al consejo de Inquisicion [...] supe que $\mathrm{P}^{\circ}$ de Valencia dixo que un libro del Monte prometía vn nuebo euangelio que se auia de publicar debaxo del poder de vn rey poderoso de la Arabia y [que] hacia gran fuerça en aquello del nueuo euangelio" $" 57$.

Castro asked for the imposition of the briefs of Clement VIII. These obliged Pedro de Valencia's circle to keep silent about the pergamino and láminas. As a Franciscan, Clement had supported Castro. However, the current pope, Paul V, was sceptical and did not give his support $^{58}$. On 6 March all papers from Valencia's group were seized by the Inquisition and silence was imposed.

Gurmendi was the object of great hostility at court: A "Memorial contra Gurmendi en el Consejo [de Estado]" of 20 February 1618 stated:

"Fran ${ }^{\mathrm{co}}$ de Gurmendi es enemigo capital con odio y rabia y mala voluntad".

In his "libelos famosos"

"muy largamente muestra el odio y ponzoña y mala voluntad $\left[^{\circ}\right]$ y diziendo el que es interprete no haze esse oficio sino de calumniador imprudentissimo $\left[{ }^{\circ}\right]$ Fran $^{\circ}$ Gurmendi es incapaz y no idoneo para interpretar ni entender estos libros" ${ }^{99}$.

Against the background of such hostility to Gurmendi and to any opposing views of the plúmbeos the reissuing of Valencia's Parecer of 26 November 1618 would certainly not have been popular ${ }^{60}$. His courageous insistence on speaking the truth, as he perceived it, had already been forcibly stated in the critique itself:

57. AS, leg. VII, I, fol. 969r. The italics are mine.

58. VALENCIA, Relaciones de Indias, I, p. 57.

59. AS, leg. VII, I, fol. 940r-v. This quotation is also cited in note 25.

60. The statement that the 1618 Sacromente copy of the Parecer had been siezed by the Inquisition in March is puzzling. The statement is either inaccurate or there was another version that was submitted. 
"Éste es el temor [fear of criticism by those whose religion is based on sentimental emotionalism and outward show] que con raçón tiene callados y retirados a muchos doctos y prudentes para que no se atreuan a deçir su pareçer en este caso. Pero yo, cubierto con la autoridad y con el valor y verdadero zelo de Vuestra Señoría Illustrísima diré mi sentimiento sençillamente, sin encubrir nada por temor ni respeto, respetando sobre todo a Dios, cuya causa se trata, y que es testigo de mi afecto [y] intençión, al qual no pueden seruir y agradar los que andan a contentar y aplaudir a los hombres" ${ }^{\prime 61}$.

\section{PEDRO DE VALENCIA'S LAST YEARS}

Valencia paid a great price for his courage and integrity ${ }^{62}$. As I detail in footnote 62 Valencia's criticism of the Granada artefacts took place during the same years in which he had visen, once again, to the defence of Arias Montano's Biblia regia. He had previously argued in favour of his mentor following the Expurgatory Index of 1607 (Rome). Valencia was at that time asked to write a paper on the passages expurgated from the Biblia regia

61. VALENCIA, Pergamino y láminas, p. 11.

62. During the years 1615-1619 Pedro de Valencia was also engaged in another very polemical controversy, that of the defence of the Biblia regia (1572) whose editor had been Valencia's mentor, Benito Arias Montano. Fr. Andrés de León had on 20 May 1615 offered to Philip III corrections of the bible, in particular of the Paraphrasis chaldaica. In the chronological table of the life of Pedro de Valencia, included in volume V of the Obras completas, Gaspar Morocho Gayo claims that this controversy was, in fact, a conspiracy organised between Andrés de León and the agente of Archbishop Castro in order to bring into disrepute the Biblia regia and seek papal approval for the pergamino and the Lead Books: Valencia, Relaciones de Indias, I, p. 53. Certainly Andrés de León's attempts to have his version of the Paraphrasis chaldaica published took place from 1615 to 1618 , at the height of the plúmbeas controversy. Dr. J.A. Jones has published the text of the decision of the University of Alcalá of 23 September 1618 which forbade Andrés de León from having his amended version printed. Dr. Jones also reproduces the censuras of nine academice, five of whom were in favour and four against. Those opposed all point out that Andrés de León has not used the original source, which was in Chaldean, and has used a later Syrian MS. Dr. Enrique de Villegas claims that having used secondary sources he has changed them in arbitrary fashion: "[...] quitando, mudando y añadiendo en muchas partes a su arbitrio [...]". This claim is also made by Gaspar Sánchez, Dr. Gante and Maestro Alonso Sánchez, professor of Hebrew. All make a statement that echoes a passage in Valencia's Parecer: the adulteration ot the Talmudic sources will incur the scorn of Jewish scholars. Once again I cite Dr. Enrique de Villegas: “[...] esa pretension misma [to correct 'errors' in the Biblia regia] puede dar motivo a los Judíos para que digan, al no darse la satisfacçion conveniente de la authentiçidad, que nos valemos de mentiras en apoyo de nuestra religion": J.A. JONES, «Censuras acerca de la impresión de la Paraphrasis chaldaica de Andrés de León: un aspecto de la amistad entre Benito Arias Montano y Pedro de Valencia», Homenaje a Pedro Sainz Rodríguez, I: Repertorios, textos y comentarios, Madrid, Fundación Universitaria Española. 1986, pp. 339-348. From this evidence León's version seems to have been an unscholarly hotch-potch. 
which were attributed to Arias Montano. His paper was influential in reducing the number of those of those in the later Index of Sandoval y Rojas $(1612)^{63}$.

Fr. Andrés de León had taught mathematics in Seville around 1608 and had taken part in the controversy about the plúmbeos but on the opposite side to that assumed by Valencia ${ }^{64}$. Since 1615 he had been attempting to publish his revised version of the Paraphrasis chaldaica which had been included in the Biblia regia. The opening paragraphs of the Advertencias of Pedro de Valencia and of his brother-in-law, Juan Moreno Ramírez, use the same critical criteria as those of the academice who voted against Andrés de León's version; they also stressed the importance of not tampering with an original text and criticised the changes made by Andrés de León for their arbitrary and unscholarly nature:

"Con facilidad y brevedad se quita de una version un vocablo y se sustituye otro sin dar razon de la causa porque se haze. Pero mostrar que ni el vocablo que estava primero se deviera quitar, ni poner el que se sustituyo, y que la version antes de trocarla es la cierta, y no despues de alterada, ni es facil ni breve. Lo primero ha hecho el padre Andres de Leon. Lo secundo emos procurado hazer nosotros y assi no an podido dejar de alargarse estas advertencias" $" 65$.

Like some of the censors who voted against the reprinting of the Paraphrasis, Valencia and his brother-in-law indicated that tampering with an original manuscript would be ridiculed by Jewish scholars and thus be counterproductive in attempts at conversion.

During 1617 and 1618 Valencia came into direct conflict with Andrés de León as he insistently demanded that the latter hand his papers over to competent academice in Alcalá and desist from circulating the favourable critique of a Fr. Palencia. On 1 August 1617 Valencia sent a memorial to the King requesting this. On 1 November Valencia's procurador sent a petition to the rector of Alcalá asking if the papers liad been submitted. On 5 December

63. J.A. JONES, «Pedro de Valencia's Defence of Arias Montano: the Expurgatory Indexes of 1607 (Rome) and 1612 (Madrid)», Bibliothèque d'H'umanisme et Renaissance, Travaux et Documents, XI, 1978, pp. 121-136.

64. L. GÓmEZ CANSECO, El humanismo después de 1600: Pedro de Valencia, Sevilla: Universidad de Sevilla, 1993 , p. 85. The author does not elaborate this point or quote sources. However, if it is true then it gives weight to the assertion of Professor Morocho Gayo cited aboye in note 61.

65. P. de VAlencia, Advertencias de Pedro de Valencia y Juan Ramirez acerca de la impresion de la Paraphrasis chaldaica, MS 502, BNM, fol 4r. The aboye passage is cited in the book mentioned aboye: GÓMEZ CANSECO, op. cit., p. 86. The Adventencias were submitted to the rector of Alcalá on 10 October 1616: VALENCIA, Relaciones de Indias, I, p. 54. 
another memorial was sent to the King asking him to proceed against León with the utmost severity as he had ignored the royal order of 21 October:

"[...] porque esta es causa de gran importancia por pertenecer [a] la Biulia Regia y tendra grandes ynconbenientes quedarse sin determinar [..]".

On 26 February 1618 the Royal Council, in reply to the memorial of Valencia, demanded that León be compelled to hand over his papers. During this time León was in touch with Pedro de Castro. In a letter to the Archbishop of 10 April León blamed Valencia for the delay in getting approval for his amended Paraphrasis. In highly emotive terms León claimed that the láminas were of heavenly origin and identified his sufferings with that of the Immaculate Conception. In September Andrés de León and Juan Moreno Ramírez were summoned before the convocation of the University of Alcalá and on 11 September a decision was given in favour of Pedro de Valencia and Juan Moreno Ramírez ${ }^{66}$. Could this victory have contributed to Valencia's decision to re-cirulate the Parecer in November of 1618 ?

Thus, during these last years of his life Valencia was fighting on two fronts, as he was both defending Arias Montano's inclusion in the Biblia regia of the original Hebraic text of the Paraphrasis chaldaica, with explanatory notes, and was, during the same period, also reiterating his criticisms of the Granada artefacts. Such undue stress ${ }^{67}$ would appear to have affected his health. According to his anonymous biographer his health was undermined during the last year of his life:

"Bivio sesenta y cuatro años con mui buena salud, hasta un año antes que muriesse, que se fue enflaqueciendo i melancolizando de manera que passava con desconsuelo i desaliento, que fue creciendo hasta que murio" ${ }^{\circ}$.

Valencia finally died on 10 April 1620 at the age of sixty-four. I shall end with the much quoted eulogy of Don Luis de Góngora (14 April):

"Nuestro buen Pedro de Valencia muriò el viernes pasado: helo sentido por lo que deuo a nuestra nacion, que ha perdido el sujeto que meior podia ostentar i oponer a los extranjeros" ${ }^{\prime 69}$.

66. «Tabla cronológica de la vida y obra de Pedro de Valencia», Valencia, Relaciones de Indias, I, pp. 53-64.

67. Such activities must have won many enemies for Valencia. It has been pointed out that his brother-in-law also suffered as he was murdered in mysterious circumstances in 1626: GómEZ CANSECO, op. cit., p. 87.

68. $\quad$ Anon., Vida de Pedro de Valencia, MS 5781, fol. 136v.

69. L. de Góngora y ARGOTE, «Carta al $\mathrm{S}^{\text {or }} \mathrm{D}$. Francisco del Corral», 14 de abril de 1620, in Obras poéticas de D. Luis de Góngora, III, ed. R. Foulché-Delbosc, New York, The Hispanic Society of America, 1921, p. 172. First cited in M. SERrano y SAnz, Pedro de Valencia. Estudio biográfico-crítico, Badajoz, Tipografía y Librería de Antonio Arqueros, 1910. 


\section{ABSTRACT}

The MSS of Pedro de Valencia's critique Sobre el pergamino y laminas de Granada, written at the behest of the Inquisitor General, Bernardo de Sandoval y Rojas, have two different dates: MS 2316 of the BNM (fols $1^{\mathrm{r}}-30^{\mathrm{r}}$ ) is dated 26 November 1607 but MS 7187 of the BNM (fols $116^{\mathrm{r}}-138^{\mathrm{r}}$ ) and MS flo. 138, vt. invent. 2, Leg. VI-VII of the Abadía del Sacromonte (fols $143^{\mathrm{r}}-163^{\mathrm{v} \text { ") }}$ ) are dated 26 November 1618. Relying on historical details and internal evidence in the Parecer itself I argue that the critique could have been written in 1607 and then resubmitted in 1618. I focus mainly on a comparison between Valencia's Parecer and the libelo of Francisco Gurmendi (1617), in which this "criado de su magestad y intérprete de lenguas orientales" defends his translation of the first two of the "Lead Books".

\section{RESUMEN}

Los manuscritos del Parecer de Pedro de Valencia Sobre el pergamino y láminas de Granada, redactado a instancias del Inquisidor General, Bernardo de Sandoval y Rojas, llevan dos fechas distintas: el Ms 2316 de la BNM (ff. 1r-30r) está fechado en 26 de noviembre de 1607 pero el Ms 7187 de la BNM (ff. 116r-138r) y el Ms flo. 138, vt. invent. 2, Leg. VI-VII de la Abadía del Sacromonte (ff. 143r-163v) llevan la fecha de 26 de noviembre de 1618. Basándome en datos históricos y en el contenido del Parecer arguyo que éste podría haberse redactado en 1607 y luego entregado otra vez en 1618. El grueso del artículo consta de una comparación entre la obra de Valencia y el libelo de Francisco Gurmendi (1617), donde este "criado de su magestad y intérprete de lenguas orientales" defiende su traducción de los dos primeros "libros plúmbeos". 